\title{
States' obligations relating to marine monitoring and observation
}

\author{
Young-Kyung Yoon
}

Received: 3 December 2010 / Accepted: 17 January 2011 /Published online: 23 February 2011

(C) World Maritime University 2011

\begin{abstract}
Ocean data determining the state of the ocean are required for various purposes. The data are needed to understand the ocean and its interrelation, for instance, with the climate as well as to provide information and benefits for numerous sectors, such as for the coastal protection or pollution control. In order to meet the multiple needs for ocean information, a global and sustained system for ocean observation activities is necessary. Steps towards such a global system have been taken within the last decades, especially by setting up the Global Ocean Observing System (GOOS). However, the existing international structures and systems have been lacking governmental support and are held to be insufficient. In this context, the questions are raised whether states are already required by international law to observe and monitor the ocean and to cooperate in doing so and whether states are even obliged to contribute to international ocean observing programmes. Although to some extent, states' obligations can be found in international conventions, such as in the UN Convention on the Law of the Sea (UNCLOS), they cannot meet all the various needs for ocean data. Specific and substantive obligations in international law meeting the multiple needs for ocean data are, however, required. If such obligations were included in the UNCLOS, issues relating to Marine Scientific Research would have to be kept in mind. Another option of creating specific commitments could be seen in a new agreement relating to the GOOS.
\end{abstract}

Keywords Ocean data - Ocean monitoring · Ocean observation · GOOS · IOC · UNCLOS

\section{Introduction}

Ocean data and information determining the state of the ocean are required to understand the ocean and its interrelation with other elements, such as the climate, to meet diverse purposes and to produce various benefits. Considering these needs for ocean data 
derived from various ocean observation activities, the question on states' obligations relating to marine monitoring and observation and the question whether there is a need for further development of the United Nations Convention on the Law of the Seas (UNCLOS) will be examined. In order to answer these questions, the various needs for marine observation and ocean data and their benefits will be illustrated to begin with (Section 2). It will be seen that a global and sustained system for ocean observation activities is necessary to meet the different needs for ocean data (Section 3), but that such a system has not been achieved yet. Although steps towards a global system have been taken within the last decades, the existing international structures and system for ocean observations are rather held to be insufficient, as it is the case with the Global Ocean Observing System (Section 4). One of the main difficulties in this context appears to be the lack of governmental support, especially in terms of financial support of a system. Thus, it will be looked at, whether states are already required to observe and monitor the ocean as well as to cooperate in or even contribute to international ocean observing programmes (Section 5). In doing so, some relevant provisions of international and regional conventions will be pointed out. Also possible states' obligations set down by the EU as well as soft law instruments will be discussed. In this context, it is necessary to be aware of the fact that marine monitoring and observation obligations cannot be understood to have the identical meaning, as observation activities are carried out for purposes of monitoring the ocean for a certain objective, e.g. to protect the marine environment (Section 5.2). Whether the existing states' obligations are sufficient to meet the needs for ocean data and for a global system or whether there is a need to establish further regulations in terms of binding provisions of international law will be considered subsequently (Section 6). The following discussion on whether the UNCLOS needs to be further developed by establishing new states' obligations relating to marine monitoring and observation will also take into account issues that arise in relation to Marine Scientific Research in terms of the UNCLOS (Section 7). Finally, other options of establishing ocean monitoring and observation obligations as well as duties to participate in a global ocean observing system by developing independent agreements will be discussed (Section 8).

\section{The need for marine observation and the need for ocean data}

\subsection{Marine observation, ocean data and its benefits}

The need for marine observation is to be seen in the findings obtained by various ocean observation methods - the ocean data. Data collected from the ocean concern a range of ocean variables such as the sea level, the sea and sea surface temperature, the ocean colour, the salinity, the height of waves, the pressure, the biochemical composition of the water, the currents and many others. ${ }^{1}$ Such ocean data are needed in order to assess the state of the ocean, to monitor it for different purposes and to

\footnotetext{
${ }^{1}$ The listed ocean properties are to be understood as a non-exhaustive enumeration. For an overview of further ocean parameters that are being and that can be observed see Ryder (2003), paragraph 2 at pp 4-9 as well as the scientific papers presented at the OceanObs'09 Conference in Venice, especially on day 2 of the Conference http://www.oceanobs09.net/agenda/day2.php (accessed on 01.12.2010). All of the following web links were all last visited on 01.12.2010.
} 
understand the global ocean, its impacts as well as its interrelation, for example on/ with the climate. The assessment of the gathered ocean information is particularly important to understand the existing threats to and from the ocean for example as regards to the coasts where people increasingly live, the (marine) environment, fisheries, coral reefs as well as climate change. Observations of the oceans globally, regionally and locally including measures or indicators of change and impact can therefore be said to be the key to understanding. Furthermore, ocean data are not merely needed for the assessment of the current state of the ocean, but also to make predictions by means of forecasts of the ocean's future state, of the climate, weather and of natural hazards. ${ }^{2}$ Based on such forecasts and other information products derived from ocean data, necessary measures such as policy decisions ranging from energy and pollution control to fisheries quota determinations can be taken or-if they already exist - can be evaluated.

Thus, ocean data obtained through observation activities and information products derived from the data provide diverse benefits for numerous sectors of activities, such as coastal protection and coastal management, flood prevention, emergency warnings, pollution control, fisheries and navigational safety. The information can also help to forecast the mechanisms and effects of climate change and global warming. ${ }^{3}$ Further, as a current issue, the oil spill in the Gulf of Mexico can be mentioned, where ocean data obtained by satellites are made available in real time to help emergency responders to track the spill and coordinate efficient cleanup efforts. ${ }^{4}$ Accordingly, ocean observation activities provide diverse benefits in the present, in the immediate future and over the years and serve different purposes such as monitoring the ocean for the protection of the marine environment.

Summing up, there are multiple needs for ocean data as the data and observational products are required for diverse fields in order to meet various purposes. In addition, marine data provide benefits for numerous sectors of activities. Monitoring the marine environment and the climate change are two of the purposes marine variables are gathered for. However, as set out above, ocean data also needs to be collected for many other reasons, such as coastal and human protection.

\subsection{Observation technologies}

To gather the ocean data needed, numerous observation technologies are deployed; complex models for computers have been developed to process the marine variables; technology disseminating data flows and marine information to transmit them and make them available are being used. In regards to ocean observation activities, data is collected from the space by satellites, in situ ('in the place'), from the coast as well

\footnotetext{
${ }^{2}$ Ryder 2003, para 3.1, p. 10-Ryder focuses on assessments and forecasts in regard to the marine environment; Conference Statement of the Ocean Obs'09 in Venice at p. 3 available under http://www. oceanobs09.net/documents/OO09_ConferenceStatement_Final.pdf.

3 Tromp and Fleming 2002, p. 279. For further benefits that can be derived from ocean observations see Adams et al. (2000).

${ }^{4}$ See http://www.ioc-goos.org/content/view/265/48/.
} 
as from the subsurface of the ocean by means of various devices such as aircrafts, ships/vessels, underwater vehicles, moorings, buoys, floats, acoustic tomography, aircraft and radars. ${ }^{5}$ Frequently, the employment of several of such devices is required within one observation project to facilitate the collection and transmission of ocean data. This is, for example, the case with the Argo Profiling Float Deployment on the High Seas, for which the temperature and salinity profiles measured by the free-floating instruments together with the position of the floats are transferred via satellite in real time. ${ }^{6}$

\section{The need for a global and sustained system}

Considering the diverse needs for ocean data gathered by the various observation methods, it is put forward that a global system for ocean observation in form of a 'multi-user, multi-purpose system is needed. Single states by themselves are not able to meet all the diverse needs for data. ${ }^{7}$ A global system is required to enable the cooperation and coordination of observation activities of different states and other actors involved in ocean observation. ${ }^{8}$ It is needed to find existing gaps - as the ocean is still undersampled both in space and in time (Alverson and Baker 2006) - and to avoid overlaps as well as to achieve maximum synergies. Furthermore, such a system would need to be a sustained system to meet not only the short-term, but also the long-term needs. An integrated global system which meets all these socio-economic needs is therefore required for systematic and sustained ocean observations on an international scale.

\section{Existing international structures and systems}

\subsection{Actors involved and existing structures - an overview}

Various actors and bodies at the global, regional and national level are involved with ocean observation activities. Cooperation, joint programmes and networks between several of the bodies already exist. ${ }^{9}$ International and intergovernmental structures with an interest in the coordination of ocean observations as well as in the joint use

\footnotetext{
${ }^{5}$ For a visual overview of the a variety of observation methods and technology available and of the kinds of variables sampled and processed, see poster illustrated for GOOS by Glynn Gorick available under http://www.ioc-goos.org/index.php?option=com_content\&task=view\&id=221\&Itemid=63; for an explanation of the poster see Brochure: GOOS Gorick Poster Explained, available under http://unesdoc.unesco. org/images/0018/001878/187825E.pdf.

${ }^{6}$ For further information on the ARGO project, see http://www.argo.ucsd.edu/index.html.

${ }^{7}$ Conference Statement of the Ocean Obs'09 Conference in Venice at p. 3 (supra, at note 3).

${ }^{8}$ For further reasons 'why we need a global system', see United Nations System-Wide Earth Watch, The Global Ocean Observation System (GOOS): a summary explanation, available under http://www.un.org/ earthwatch/about/docs/goosflyr.htm.

${ }^{9}$ For a preliminary list of sustained ocean observing networks, see Annex 5 of the report of the Integrated Framework for Sustained Ocean Observations Task Team-IFSOO-TT (post-OceanObs'09 working group), second teleconference, 25th March 2010, available under http://www.oceanobs09.net/wg/ meetings.php.
} 
of its products are also already in operation. ${ }^{10}$ The Intergovernmental Oceanographic Commission (IOC) of United Nations Educational, Scientific and Cultural Organization (UNESCO), the World Meteorological Organization, the United Nations Environment Program and the International Council for Science are part of the structure. These bodies co-finance the Global Ocean Observing System (GOOS), which will be described in more detail below. In addition, however, there are many other actors and fora that coordinate marine observations and ocean research, such as private and public marine research institutions, oceanographic institutes and associations of such, meteorological as well as oceanographic agencies and many more. ${ }^{11}$

Mapping all of them, their functions as well as their relations to each other, their joint projects and their role within the structure, however, would prove to be rather difficult and would present a major challenge as one common infrastructure does not yet exist. ${ }^{12}$ The existing international ocean observation initiatives are said to be fragmented and their 'present governance' approach to ocean observations to be insufficient, so that a greater effort would be needed to advance the coordination across countries and disciplines of ocean observations. ${ }^{13}$ An international structure or mechanism of ocean observation activities sufficient to meet the needs for a global system as set out above can therefore not be said to exist yet. ${ }^{14}$

\subsection{The global ocean observing system}

The GOOS which was conceived as an international system for gathering data of the oceans to provide international coordination of sustained observations ${ }^{15}$ can also not yet be seen as a sufficient global system for ocean observation activities. The GOOS as a programme was created 1991 by a non-binding resolution of the IOC. It is an independent unit of the IOC, which is one of its co-financers. The work of the GOOS, for a large part, focuses on two of its modules: the climate and the coastal module. ${ }^{16}$ Its primary function is to be a system for sustained, coordinated, international ocean observations and some have envisaged the system to become a global system similar to the World Weather Watch. Although the GOOS is designed to meet all the various needs for ocean data as described above, ${ }^{17}$ GOOS is not yet a or even the 'truly global system' (Alverson and Baker 2006). In order to become such a global system, the existing gaps would have to be filled. This applies for the coastal module as well as

\footnotetext{
${ }^{10}$ For a list of international and intergovernmental organizations with interest in ocean observations, see Annex 4 of the report of the second teleconference of the IFSOO-TT, ibid.

${ }^{11}$ Ibid, for further bodies and actors.

${ }^{12}$ See the report of the second teleconference of the IFSOO-TT at p. 2, available at http://www. oceanobs09.net/wg/meetings.php.

${ }^{13}$ Group on Earth Observations Statement at the Ocean Obs'09 Conference in Venice, available under http://www.oceanobs09.net/documents/GEO_statement_OceanObs09_18SEP.pdf.

${ }^{14}$ Conference Summary of the OceanObs'09 Conference 2009 in Venice, at p. 3, available under http:// www.oceanobs09.net/documents/OO09_Conference_Summary_vREVISED_7dec09.pdf.

${ }^{15}$ United Nations System-Wide Earth Watch, The Global Ocean Observation System (GOOS): a summary explanation, available under http://www.un.org/earthwatch/about/docs/goosflyr.htm.

${ }^{16}$ In 1992, GOOS was envisioned as consisting of the following five modules: Climate monitoring, marine living resources, coastal zone management and development, health of the ocean and marine meteorological and oceanographic services.

${ }^{17}$ See Alverson 2008b; see also http://www.ioc-goos.org/content/view/12/26/ for what GOOS is designed for.
} 
for the climate module, even though the latter has been through substantial progress towards implementation. One of the essential problems in this context is the funding problem and the lack of governmental support. States are unwilling to commit themselves to finance the modules in a sustainable way or to contribute through national observation activities on a long-term scale.

\section{Existing states' obligations}

In the light of the aforementioned - the various needs for ocean data and the need for a global system which has not as such been achieved yet - the question can be raised whether states are possibly already required to monitor, to observe, to cooperate or even to contribute to a global ocean observing system.

\section{1 "Novel" question}

Although states' obligations relating to ocean data collection are to some extent being presumed ${ }^{18}$ and international conventions that govern observation activities have been referred to and even partly listed, ${ }^{19}$ the question on whether such states' obligations already exists and where these can be found has not yet - as it seemsbeen explicitly raised and answered. So far, the legal questions raised in this context have rather taken a different or even opposite perspective by asking whether different kinds of observation activities are restricted by international law, especially by the UNCLOS. ${ }^{20}$ In particular, the issue - which will be looked at closer-on whether certain observation activities constitute marine scientific research in terms of the UNCLOS has been discussed repeatedly (Mateos and Gorina-Ysern 2010).

\subsection{Terms: marine monitoring and marine observation}

In order to examine whether states are required by international law to monitor and observe the ocean or even to cooperate and contribute to a global ocean observing system, the terms marine monitoring and observation and their meaning have to be looked at and defined for the purpose of this paper.

Although no explicit legal or oceanographic definition of these terms seems to exist, it is evident from its ordinary meaning ${ }^{21}$ that there is a difference in connotation when it is referred to monitoring activities or to observation activities. Marine monitoring is

\footnotetext{
${ }^{18} \mathrm{Ibid}$, at p. 12, where it is pointed out that the decrease of funding of GOOS would stand in contrast to treaties and conventions that depend on ocean data for their implementation.

19 Ryder 2003, Annex B where some 'Conventions that encourage marine assessment, research and monitoring' are listed; see also Annex 3 of the report of the Integrated Framework for Sustained Ocean Observations Task Team-IFSOO-TT (post-OceanObs'09 working group), second teleconference, 25th March 2010 (supra note 19); Conference Summary of the OceanObs'09 Conference 2009 in Venice, at p. 2, (supra note 22).

${ }^{20}$ United Nations Convention on the Law of the Sea (UNCLOS), done at Montego Bay, 10 December 1982, entry into force 16 November 1994, 1834 UNTS 397 [Registration Number 31363].

${ }^{21}$ Article 31 of the Vienna Convention on the Law of Treaties, 1969, entry into force, 27 January 1980, 1155 UNTS 331.
} 
more extensive in its meaning and to be understood as a long-term activity of checking a progress or quality of the ocean over a period of time. ${ }^{22}$ It is pursued for a specific purpose, such as to monitor the marine environment on a long-term scale. ${ }^{23}$ Ocean observation, in contrast, refers to the ocean observation activities or methods themselves, i.e. the various activities of collecting ocean data. Such observation activities are therefore also conducted in order to accomplish monitoring obligations. This interpretation of the terms can also be inferred from Art. 204 UNCLOS which is located in Section 4 headed 'Monitoring and Environmental Assessment' of Part XII UNCLOS, the part concerned with the protection and preservation of the marine environment. Article 204 paragraph 1 UNCLOS describes what 'Monitoring of the risks or effects of pollution'- the heading of the Article - entails, that is 'to observe, measure, evaluate and analyse, by recognised scientific methods, the risks or effects of pollution of the marine environment.

Thus, states' obligations to marine monitoring can be understood as obligations to keep the ocean under systematic review on a long-term basis for a certain purpose whereas marine observations obligations encompass the duty to collect ocean data, e.g. by measuring certain properties of the ocean. ${ }^{24}$ Even if it can be argued that ocean observation is necessary to accomplish the task of ocean monitoring, the terms cannot automatically be understood to include the other meaning when looking at monitoring and observing obligations.

\subsection{Sources}

States obligations relating to marine monitoring and observation can be found in different international conventions - a recognised source of international law listed in Article 38 paragraph 1 lit. (a) of the Statute of the International Court of Justice. ${ }^{25}$ These obligations are largely set down in various international instruments for the protection of the (marine) environment and in an agreement concerned with climate change. In addition, ocean observation and monitoring activities are asked for in several documents that can be regarded as 'soft law'. Furthermore, monitoring duties on the level of the European Union exist.

\subsubsection{International conventions}

1. Conventions and provisions for the protection of the (marine) environment

(a) UNCLOS, $1982^{26}$

The UNCLOS is often referred to as the "Constitution of the Sea" and an

\footnotetext{
${ }^{22}$ See the description of 'to monitor' in Oxford dictionaries, online version, available under http:// oxforddictionaries.com/view/entry/m_en_gb0530190\#m_en_gb0530190.

${ }^{23}$ See Roach 2009, p. 82 where he refers to 'data that is used for the monitoring and forecasting of weather, climate and ocean state'.

${ }^{24}$ The term 'operational Oceanography' in turn also seems to have a different connotation. It is defined as "the activity of systematic and long-term routine measurements of the seas and oceans and atmosphere, and their rapid interpretation and dissemination", see explanation of EuroGOOS of that term, available under. http://www.eurogoos.org/content/content.asp?menu=0090000_000000_000000.

${ }^{25}$ Statute of the International Court of Justice, 26 June 1945, 33 UNTS 993.

${ }^{26}$ Supra note 35.
} 
"overall framework for ocean activities", 27 because it is concerned with nearly all aspects of the law of the sea. ${ }^{28}$ Having been ratified by 160 states at present $^{29}$ it has a particular importance as a source of the law of the sea. ${ }^{30}$

Obligations relating to marine monitoring or to marine observation in terms of general obligations to meet all the various needs for ocean data, as described above, cannot be found in UNCLOS. However, monitoring and observation commitments as well as obligations to cooperate in research programmes and ocean data exchange for the purpose of protecting the marine environment are to some extent set out in Article 204 and 200 of part XII of UNCLOS - the part devoted to the marine environment which has been described to be a general and binding code of marine environmental law.

\section{- Article 204 paragraph 1 UNCLOS}

Article 204 paragraph 1 UNCLOS entitled 'Monitoring and Environmental Assessment' requires states to:

endeavour, as far as practicable, directly or through the competent international organizations, to observe, measure, evaluate and analyse, by recognised scientific methods, the risks or effects of pollution of the marine environment.

Monitoring and observing the risks or effects of pollution however, can only be accomplished through ocean observation in terms of collecting ocean parameters, such as sampling and a unified system of calibration. States' obligation to monitor and observe the ocean for the purpose of protecting the marine environment could therefore be said to be set out in Article 204 paragraph 1 UNCLOS - at least 'indirectly' as they are required as prerequisites to monitor and observe the risks and effect of marine pollution. However, it is contended that the provision sets out an obligation of routine monitoring rather than fundamental research. For that reason, it could be argued that obligations to ocean observation, meaning collecting data by various means, are not stipulated by Article 204 paragraph 1 UNCLOS. As discussed before, monitoring cannot automatically be understood to include observation activities. ${ }^{31}$ Even if the provision was read as to include ocean observation duties, explicit obligations to specific measures are not set out. The commitments would rather have to be understood as 'faint' or 'weak', as states shall merely "endeavour" "as far as practicable" to accomplish these tasks.

\section{- Article 200 UNCLOS}

Article 200 UNCLOS entitled 'Studies, research programmes and exchange of information and data' belongs to part's XII Section 2 on 'global and regional cooperation'. It implies and reflects the recognition that a comprehensive approach to the protection of the marine environment requires the study of the

\footnotetext{
${ }^{27}$ Graf Vitzthum 2006, p. 46, margin no. 106, at note 179 for further references.

${ }^{28}$ Graf Vitzthum 2006, p. 46, margin no. 106.

29 or a list of states that have ratified the treaty, see http://www.un.org/Depts/los/reference_files/ status2010.pdf.

${ }^{30}$ Graf Vitzthum 2006, p. 46, margin no. 106.

31 Supra, at 5.2.
} 
present state of the ocean to begin with and that an interdisciplinary approach as well as the coordination of national and international research and data collection programmes is needed. Although an obligation to monitor and observe the ocean on itself is not established by Article 200 UNCLOS, sentence 1 of the provision obliges the state parties to cooperate for the purpose of the protection of the marine environment. States' obligations to cooperate

directly or through competent international organizations, for the purpose of promoting studies, undertaking programmes of scientific research and encouraging the exchange of information and data acquired about pollution of the marine environment

are stipulated in Article 200 sentence 1 UNCLOS. Furthermore, states shall

endeavour to participate actively in regional and global programmes to acquire knowledge for the assessment of the nature and extent of pollution, exposure to it, and its pathways, risks and remedies. ${ }^{32}$

Duties to cooperate with other states in order to acquire knowledge about the ocean, to participate and contribute to international ocean observation programmes are therefore laid down in UNCLOS. However, substantive and concrete obligations as regards how to meet these duties cannot be made out in UNCLOS. Furthermore, these obligations only exist with regard to the specific purpose of part XII of UNCLOS - the protection of the marine environment.

(b) The Agreement for the Implementation of the Provisions of the UNCLOS relating to the Conservation of Straddling Fish Stocks and Highly Migratory Fish Stocks (Fish Stocks Agreement), 1995 33

The Fish Stocks Agreement has as its objective to ensure the long-term conservation and sustainable use of straddling fish stocks and highly migratory fish stock. Its Article 5 lit. (k) and lit. (l) commit the contracting states to promote and conduct scientific research in support of fishery conservation and management as well as to implement and enforce conservation and management measures though effective monitoring, control and surveillance. ${ }^{34}$ Furthermore, Article 14, paragraph 3 of the Fish Stocks Agreement obligates states, in alia, to cooperate to strengthen scientific research capacity in the field of fisheries. It could be argued that ocean observation and monitoring is necessarily required to achieve the agreements' objective and that therefore the term of scientific research would need to be read to include ocean observation activities. However, such an interpretation

\footnotetext{
${ }^{32}$ This qualification reflects the concern that the potential burden imposed on developing states could be too great, see Nordquist et al. 1999, p. 93. The 'weaker' obligation to merely 'endeavour' to participate, however, applies to all, not only developing, states parties.

${ }^{33}$ Agreement for the Implementation of the Provisions of the UNCLOS relating to the Conservation of Straddling Fish Stocks and Highly Migratory Fish Stocks (Fish Stocks Agreement), done at New York, 4 December 1995, entry into force, 11 December 2001, 2167 UNTS 88 [Registration Number 37924].

34 The obligation of Article 5 (j) to collect and share complete and accurate data concerning fishing activities cannot be regarded as an obligation related to ocean monitoring and observation in terms of the aforementioned, because data on fishing activities do not encompass parameters of the ocean itself.
} 
of the term, particularly in the light of the principles of Article 31 of the Vienna Convention on the Law of Treaties, ${ }^{35}$ would be too far reaching, as explicit ocean observation and monitoring obligations are not set out.

(c) Convention on Biodiversity, $1992^{36}$

One of the objectives of the Convention on Biodiversity (CBD) is the conservation of biological diversity and the sustainable use of its components. ${ }^{37}$ In order to achieve this objective, Article 7 lit. (b) CBD obliges the contracting parties 'as far as possible and as appropriate' to monitor the components of biological diversity through sampling and other techniques. Furthermore, states are also committed to monitor the effects of processes which have or are likely to have an adverse impact on the conservation and sustainable use of biological diversity through sampling and other techniques (Article 7 lit. (c) CBD). Data derived from such monitoring activities, in addition, are to be maintained and organised, as Article 7 lit. (d) CBD stipulates. These obligations to sample data and use other techniques to gather data for the stated objective also apply to data from the sea and thus, for ocean data. However, it might be argued that this is only the case for data from certain maritime zones of the sea as - according to Article 4 lit. (a) CBD - the Convention is only applicable to components of biological diversity within zones of national sovereignty. For areas outside the national sovereignty, the agreement is applicable only to the processes and activities under the control of a state party regardless of where the effects of these activities occur (Article 4 lit. (b) CBD). When interpreted together with the provisions of the UNCLOS concerning the maritime zones, the obligations to sample data and use other techniques to gather data of components of biological diversity could be understood to apply to the components of biological diversity merely within the territorial water, archipelagic waters and the Exclusive Economic Zone. ${ }^{38}$ Article $5 \mathrm{CBD}$, in this case, encourages the states to international cooperation in respect of areas beyond national jurisdiction.

(d) The Convention on the Prevention of Marine Pollution by Dumping of Wastes and other Matter, $1972^{39}$

The Convention on the Prevention of Marine Pollution by Dumping of Wastes and other Matter, commonly known as 'The London Convention 1972 ', provides an international regime for the disposal of wastes at sea from ships, platforms and aircraft. ${ }^{40}$ Its Article VI lit. (d) requires the contracting parties to designate authorities to monitor the condition of the

\footnotetext{
$\overline{35}$ The Vienna Convention on the Law of Treaties, 1969, entry into force, 27 January 1980, 1155 UNTS 331.

${ }^{36}$ Convention on Biodiversity, 1992. Adopted during the Earth Summit in Rio de Janeiro, 1760 UNTS 79

${ }^{37}$ See Article 1 CBD for its objectives.

${ }^{38}$ Ibid.

${ }^{39}$ Convention on the Prevention of Marine Pollution by Dumping of Wastes and other Matter, 1972, done at London, 29 December 1972, entry into force 30 August 1975, 1046 UNTS 138 [Registration Number 15749].

${ }^{40}$ Ryder 2003, Annex B, para. B.6, p. 36.
} 
seas for the purposes of the Convention, whereby this is to be done also in collaboration with competent international organisations. In order to achieve its objective of protecting the marine environment, states are to give special attention to co-operation in the field of monitoring and scientific research (Article VIII London Convention 1972).

Marine monitoring obligations with the purpose of protecting the marine environment can therefore also be found in this agreement.

(e) Convention for the Protection of the Marine Environment of the Baltic Sea Area (Helsinki Convention), $1992^{41}$

The Helsinki Convention was set up to protect the marine environment of the Baltic Sea. ${ }^{42}$ Article 24 entitled 'scientific and technological cooperation' contains state obligations to co-operate in the fields of science and requires research and monitoring activities in the Baltic Sea (para. 1). Its paragraph 2 further requests the exchange of data as well as contribution to programmes aimed at developing methods that assess pollution. Explicit obligations to ocean observation activities, however, are not set down in the Helsinki Convention.

(g) The Convention on the Protection of the Marine Environment of the NorthEast Atlantic Conventions (OSPAR Convention), $1992^{43}$

The Oslo and Paris Conventions are the regulatory agreements for the prevention of pollution in the maritime area of the North East Atlantic. They were renegotiated and combined into a single Convention, known as the OSPAR Convention, in 1992. ${ }^{44}$ Implementation of the Convention takes place by a Commission of the Contracting Parties. An Environmental Assessment and Monitoring Committee collects and makes available scientific information on the status of Convention waters. ${ }^{45}$ In light of these bodies, Article 6 in connection with Annex IV of the OSPAR Convention commits the parties to undertake joint assessments of the quality status of the marine environment. Monitoring in terms of the OSPAR Convention means the repeated measurement of the quality of the marine environment and each of its compartments, including the water itself (Article 1 paragraph 1 lit. (a) Annex IV). Unlike the other monitoring obligations that have been illustrated this far, the OSPAR Convention by explicitly defining the term of monitoring for its purpose can be interpreted to include the various methods of ocean data collection. Moreover, obligations to cooperate in carrying out monitoring programmes are set down in Article 2 lit. (a) Annex IV.

\footnotetext{
${ }^{41}$ Convention on the Protection of the Marine Environment of the Baltic Sea Area (Helsinki Convention), 1992, done at Helsinki, 9 April 1992, entry into force, 17 January 2000, 2099 UNTS 197 [Registration Number 36495].

42 Ryder 2003, Annex B, para. B.8, p. 37.

${ }^{43}$ Convention on the Protection of the Marine Environment of the North-East Atlantic Conventions (OSPAR Convention), 1992, entry into force, 25 March 1998 (1993), 23 LOSB 32.

${ }^{44}$ Ryder 2003, Annex B, para. B.9, p. 37.

${ }^{45}$ For the functions of ASMO, see its terms of reference available at http:/www.ospar.org/html_documents/ ospar/html/01-04e_terms_of_reference.pdf.
} 
2. Climate change

- UN Framework Convention on Climate Change, $1992^{46}$

The UN Framework Convention on Climate Change (UNFCCC) seeks to stabilise atmospheric concentration "at a level that would prevent dangerous anthropogenic interference with the climate system" (Article 2 UNFCCC). In order to achieve this objective, Article 4 paragraph 1 lit. (g) UNFCCC requires states to co-operate in different kinds of research, systematic observation and development of data archives related to the climate system. In doing so, the Convention commits the states parties, according to Article 5 lit. (a) UNFCCC, to:

support and further develop, as appropriate, international and intergovernmental programmes and networks or organizations aimed at defining, conducting, assessing and financing research, data collection and systematic observation, taking into account the need to minimise duplication of effort

Furthermore, for carrying out the obligation of Article 4 paragraph 1 lit. (g) UNFCCC, the support of international and intergovernmental efforts to strengtheninter alia - systematic observation capacities and capabilities as well as the promotion of access to, and of the exchange of, data and analyses thereof obtained from areas beyond national jurisdiction is requested from the states (Article 5 lit. (b)).

As the ocean and the climate can affect each other in various ways - the ocean is an important sink of anthropogenic $\mathrm{Co} 2{ }^{47}$ - the bodies of the UNFCCC have been aware of the importance of understanding and monitoring the coupled ocean-atmosphere system. ${ }^{48}$ The contracting states, for instance, have been asked to report their participation in GOOS through their provision of oceanographic observation. ${ }^{49}$ The explicit obligations of the UNFCCC to contribute to data collecting, illustrated above, therefore include the obligations to participate in and contribute to a global ocean observing system for collecting ocean data-for the objective of the Convention.

\subsubsection{Soft law}

- Agenda 21, 1992 - Chapter 17: Protection of the Oceans, All Kinds of Seas, Including Enclosed and Semi-Enclosed Seas, and Coastal Areas and the Protection, Rational Use and Development of Their Living Resources ${ }^{50}$

Chapter 17 of the Agenda 21, a non-binding declaration of principles and a programme of action for the environment for the twenty-first century, is devoted to protection of the oceans. Seven programme areas within Chapter 17 define for each of them the basis for action, the objectives to be achieved, the activities to be carried

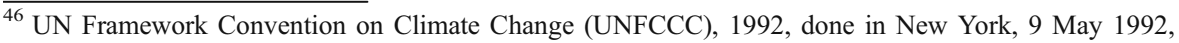
entry into force 21 March 1994, 1771 UNTS 107 [Registration Number 102-38].

47 Statement of the Ocean Obs'09 in Venice at p. 3 (supra, at note 3).

${ }^{48}$ Tromp and Fleming 2002, p. 279. For the background on the work of GOOS and its relation to the Global Climate Observing System (GCOS) in support of the UNFCCC see Background in the Progress Report on the Implementation of the Global Observing System for Climate in Support of the UNFCCC 2004-2008, at p. $15 \mathrm{ff}$.

49 UNFCCC Conference of the Parties, FCCC/CP/1999/7, http://unfccc.int/resource/docs/cop5/07.pdf.

50 A/CONF.151/26 (Vol. II), 13 August 1992.
} 
out and the means of implementation. Requests and suggestions relating to the collection, analysis and distribution of data and information from the oceans and all seas as well as to the cooperation in doing so can be found in several parts of these different programme areas. To support the development of ocean observation programmes, for instance, is asked for within programme area E. ${ }^{51}$ To support the role of the IOC as well as the GOOS is even explicitly referred to in this context. $^{52}$ These provisions, however, do not constitute binding obligations, as the Agenda 21 by itself is not a binding instrument, but rather a soft law instrument.

\subsubsection{EU sources}

1. Marine Strategy Framework Directive

At the level of the European Union, obligations relating to marine monitoring can be found in the EU Marine Strategy Framework Directive. ${ }^{53}$ The Directive outlines a legislative framework for an ecosystem-based approach to the management of human activities which supports the sustainable use of marine goods and services. The overarching goal of the Directive is to achieve 'Good Environmental Status' by 2020 across Europe's marine environment. ${ }^{54}$ For the implementation of the Directive, the member states are required to develop strategies for their marine waters. These must among other points contain a detailed assessment of the state of the environment. ${ }^{55}$ In order to assess the state of the marine environment, Article 11 of the Directive sets down the obligation to establish marine monitoring programmes based on different parameters as written down in Annex III, an indicative list. ${ }^{56}$ Explicit obligations to implement the Directive by certain ocean observation activities cannot be found.

\section{European Marine Observation and Data Network}

A new European Marine Observation and Data Network (EMODNET) was proposed by the European Commission in 2006 with the purpose of improving the availability of high quality ocean data for the EU. ${ }^{57}$ Its development has been in progress since; a roadmap has been published in $2008 .^{58}$ The basic design principles of EMODNET have been, inter alia, the collection of data once and the use of it for many times. ${ }^{59}$ Binding states' obligations related to marine monitoring and observation and obligations to cooperate have not yet been set down.

\footnotetext{
${ }_{51}$ Agenda 21, Chapter 17, para. 17.103.

52 Agenda 21, Chapter 17, para. 17.102 lit (b).

53 Directive 2008/56/EC of the European Parliament and the Council of 17 June 2008, establishing a framework for community action in the field of marine environmental policy (Marine Strategy Framework Directive), L 164/28.

${ }^{54}$ Report of the second teleconference of the IFSOO-TT at p. 8 (supra, at note 19).

55 See http://ec.europa.eu/environment/water/marine/index_en.htm.

${ }^{56}$ For information on Germany's implementation of the monitoring obligations of the Marine Strategy Directive, see for instance http://www.bfn.de/habitatmare/de/monitoring-anforderungen.php.

${ }^{57}$ For detailed information on EMODNET, see http://ec.europa.eu/maritimeaffairs/emodnet_en.html\#1.

58 SEC 2009 499, Commission Staff Working document, Building a European marine knowledge infrastructure: Roadmap for a European Marine Observation and Data Network (Roadmap EMODNET).

${ }^{59}$ See Roadmap EMODNET at p. 25.
} 


\subsubsection{Summary—existing states' obligations}

Several international conventions already require states to monitor and observe the ocean to some extent and even to co-operate within international organisations; these obligations are set down for specific purposes, especially for the protection of the marine environment and for monitoring the climate change. In some cases these obligations constitute regional agreements only. General states' obligations, however, to collect ocean data independent of one certain objective, i.e. in order to meet all the various needs illustrated, cannot yet be found in international law. Some of these obligations are even qualified; states, for instance, are in some cases merely required to endeavour to carry out certain actions. Moreover, it needs to be noted that monitoring obligations cannot automatically be interpreted as observation obligations.

\section{Need for (further) states' obligations?}

Regarding the aforementioned, it can be said that a need for further action relating to marine monitoring and observations exists. The present obligations are insufficient to meet the various needs for ocean data as well as the need for a global system.

Nevertheless, it might be debatable, whether further action would have to be taken in form of further binding obligations or whether non-binding, but other effective measures would be available and would constitute a better solution. ${ }^{60}$ Especially in the light of missing long-term funding, commitments of states and their unwillingness to contribute towards a global system, the establishment of obligations in international law could be regarded as a good means to meet the present needs and insufficiencies (Alverson and Baker 2006).

\section{Need for a further development of UNCLOS?}

One option to be considered when contemplating further binding obligations could be to further develop UNCLOS by amending existing or inserting new provisions.

\subsection{Possible ways for a further development of UNCLOS}

One could think of amending Article 200 and 204 UNCLOS by establishing absolute obligations to carry out observation activities and to participate in or contribute to a global observing system. These obligations would have to be detached from the - presently specific and only - purpose of protecting the marine environment in order to meet the various needs for ocean data. Thus, such

\footnotetext{
${ }^{60}$ See work of the Working Group after the OceansObs'09 Conference, which is called for to recommend a structure for enhanced global sustained ocean observing system over the next decade, available at http:// www.oceanobs09.net/wg/index.php. Legal solutions in form on further binding obligations related to ocean monitoring, observation or cooperation have so far not been discussed.
} 
obligations would probably be better set down in another part of UNCLOS, as Article 200, 204 UNCLOS are presently placed in Part XII UNCLOS. ${ }^{61}$

\subsection{Marine Scientific Research}

Establishing general obligations to monitor the ocean, to carry out ocean observation activities and to cooperate within as well as to contribute to a global ocean observing system could affect or even contradict existing provision of UNCLOS. These would necessarily have to be kept in mind when suggesting a further development of UNCLOS. The regulations on Marine Scientific Research (MSR) as set down in Part XIII UNCLOS could be affected by new obligations. This would be the case, if ocean observation activities, as described, were qualified as MSR within the meaning of UNCLOS; this in turn would entail different legal implications depending on the maritime zone of UNCLOS where observation activities are carried out. If qualified as MSR, coastal states have various rights to restrict activities relating to the collection of ocean data: Pursuant to Article 246 paragraph 1 UNCLOS, for instance, they have the right to regulate MSR within their exclusive economic zone ${ }^{62}$ and on their continental shelf $^{63}$; according to Article 246 paragraph 2 UNCLOS, their consent is required when MSR is carried out in the zones mentioned. A further example is Article 21 paragraph 1 lit. (g) UNCLOS: Coastal states have the right to adopt laws and regulations relating to innocent passage through the territorial sea ${ }^{64}$ in respect to MSR. ${ }^{65}$ Classifying ocean observation activities as MSR consequently would have substantial legal impact.

Whether systematic and regular ocean observing activities to collect data constitute MSR is, however, greatly debated. This is mainly due to the fact that UNCLOS lacks a comprehensive definition of MSR. The states are rather asked to promote through competent international organisations the establishment of general criteria and guidelines to assist States in ascertaining the nature and implications of MSR as set down in Article 251 UNCLOS. In general, MSR is understood to include all activities aimed at the increase of mankind's scientific knowledge of the marine environment and its processes and the term MSR is applied to a range of scientific disciplines concerned with the study of the oceans. ${ }^{66}$

A number of coastal states view ocean observing activities - carried out as part of operational oceanography ${ }^{67}$ — as a modality of MSR governed by Part XIII of 1982 UNCLOS. This view finds its basis in a strictly formal interpretation of 'any activity intended to increase knowledge about the marine environment'. Other states, including leading researching states, as well as legal scholars are of the opinion that

\footnotetext{
${ }^{61}$ It should be noted, that the author does not imply that such an amendment option would be feasible/ realistic, but merely attempts to consider possible options.

${ }^{62}$ Article 55 UNCLOS.

63 Article 76 UNCLOS.

${ }^{64}$ Article 2 UNCLOS.

${ }^{65}$ For detailed account on the UNCLOS regulation of MSR in the different maritime zones see, for instance, F. Wegelein, Marine Scientific Research, 2005, Chapter 4, at p. 175 ff.

${ }^{66}$ See Graf Vitzthum 2006, p. 426, margin number 233.

${ }^{67}$ See supra note 40 for the term of operational oceanography.
} 
activities carried out for operational oceanography are accepted not to fall under the term MSR (Mateos and Gorina-Ysern 2010). They refer to activities of the World Meteorological Organizations that also partly involve ocean data collection and that have been accepted not to be covered by Part XIII UNCLOS. ${ }^{68}$ Operational ocean data, as it is suggested, should be treated in an analogous manner. At least, it is put forward, where the marine environment is at stake, sovereignty rights and resource considerations of MSR may well be outweighed.

When considering the further development of UNCLOS for establishing new obligations relating to marine monitoring and observation, these interpretative uncertainties would have to be kept in mind and dealt with (Mateos and Gorina-Ysern 2010). A specific protocol agreeing on the non-applicability of the MSR provisions could, for instance, be set up.

\subsection{UNCLOS as the legal framework for activities at sea}

An argument in favour of a further development of UNCLOS instead of developing a new international agreement can be seen in the importance of UNCLOS for the law of the sea as it sets the legal framework for the regulation of all kinds of activities at sea. It is therefore maintainable that there is a need for a further development of UNCLOS.

\section{Other options}

One could also think of other ways to establish states' obligations relating to ocean monitoring, to observation and to cooperation within a global system with the purpose of meeting all the various needs for ocean data.

\subsection{IOC Agreement/UNESCO Agreement}

An option which has been suggested by Alverson and Baker (2006) is the development of a UNESCO/IOC Convention that commits nations to sustaining an integrated ocean-observing system-the GOOS. In their view, such a convention, especially in respect of financing commitments, would lead to a better understanding of the ocean and therefore meet the various needs for ocean data. When focussing on commitments to sustain GOOS, it has been proposed that a multilateral agreement would merely be adequate concerning the climate module of the GOOS, because observations for climate were largely made by a handful of countries. Thus, fewer interests at stake would have to be reconciled, making an agreement feasible. The gaps of the coastal module of the GOOS, on the other hand, would better not be filled with the development of an agreement, because many conflicting interests were at stake that would not be tractable on the global scale. ${ }^{69}$

An argument which can be put forward against a UNESCO/IOC Convention can be seen in the fact that the UNESCO is a science and educational agency and

\footnotetext{
${ }^{68}$ See response of Alexander Yankov - the chairman of the Third Committee - to the statement of the World Meteorological Organization in UN Doc. A/CONF.62/L.61, paragraph 8. It is, however, to be noted that the WMO in its statement had in mind activities carried under its Voluntary Observing Ship Scheme. ${ }^{69}$ Supra, at p. 21.
} 
therefore could be regarded not to be a compatible home for routine and operational activities.

\subsection{Independent GOOS Agreement}

Another option for establishing obligations relating to marine monitoring and observation, including cooperation and contributing duties could be seen in the development of an independent GOOS Agreement. Obligations to sustain and develop the GOOS would have to be set out, although a differentiation between the modules of the GOOS might be required, as illustrated above.

A great advantage of such a GOOS Agreement lays in the system and structure of the GOOS which have already been achieved up to the present. Even though gaps and insufficiencies exist, it seems sensible to sustain and further develop the achieved system. Obligations to participate within the GOOS and to contribute to it would help to meet one of the system's largest difficulties: the lack of financial commitments. A further step towards an effective global system similar to the World Weather Watch, as envisaged by some, could herewith be taken.

\subsection{Regional approach}

Finally, apart from a global solution to meet all the various needs for ocean data, one could also consider a regional approach as 'different global regions identify different timescales of the whole spectrum of forecastable marine processes as potentially important'. The effect of the El Nino-Southern Oscillation, for example, is minimal in Europe. ${ }^{70}$ However, it has to be kept in mind, that 'the whole picture' of the state of the ocean and long-term impacts and interrelations can only be understood by taking a global approach. Where a regional approach and perspective is needed, regional cooperation and coordination could rather be carried out as part of a global system; as it is already the case in regard to the coastal elements of GOOS which is to a large extent implemented by the GOOS regional alliances. ${ }^{71}$

\section{Conclusion}

It has been illustrated that the various needs for marine observation and ocean data as well as the need for a global system of ocean observation activities are not be met by the existing international structures and systems. Although states' obligations to observe the ocean, to monitor the ocean for specific reasons and to contribute to a global system of ocean observation can be found in international conventions to some extent, it is put forward that these are insufficient to meet all the various needs mentioned. The existing

\footnotetext{
70 Supra, at P. 288.

${ }^{71}$ See Alverson 2008c, p. 33. The European Union, which seems to take a regional approach to the issue of ocean observation data regarding its work on EMODNET will therefore also have to take into account the role of the European regional alliance-EuroGOOS; see EuroGOOS Notes from the discussion on the future of EuroGOOS EG09.27, 7 October 2009, available at http://www.eurogoos.org/documents/ eurogoos/downloads/eg09_27eurogoosfuture091007.pdf.
} 
obligations are set down for specific purposes, in particular to monitor and protect the marine environment or to monitor the climate change. Monitoring obligations can however, not automatically be understood as a duty to carry out certain observation activities. Furthermore, some of the conventions apply to specific regions only and some provisions are qualified regarding their degree of obligation. Thus, it can be said that global, general and absolute obligations relating to marine monitoring and observation as well as to contributing to an international system cannot yet be found. Such binding obligations in international law would, however, be required - especially in view of the present reluctance of governments to financially contribute to a global system. The commitments needed could be achieved by further developing the UNCLOS by means of amendment - although the issues relating to MSR would have to be kept in mind. Other options could be the creation of a new agreement, either based with the UNESCO/ IOC or the creation of an independent GOOS Agreement. The options looked at should be regarded as mere 'first ideas' as it seems that this issue has not explicitly been discussed yet. Whether they can be realised depends on many factors. Especially, it is questionable whether states will be willing to create new ocean observation obligations and in particular-financing obligations. Other options of meeting the needs specified above - whether in form of establishing binding obligations or in form of soft law or other means - might also be thought of in the future.

Acknowledgements The paper was written in the course of a seminar on the law of the sea at the University of Hamburg held by Prof. Dr. Peter Ehlers, Prof. Dr. Rainer Lagoni and Prof. Dr. Marian Paschke, whom the author would like to thank.

\section{References}

Adams R, Brown M, Colgan C, Flemming N, Kite-Powell H, Bruce M, Mjelde J, Solow A, Teisberg T, Weiher R (2000) The economics of sustained ocean observations: benefits and rationale for public funding. A Joint Publication of the US National Oceanic and Atmospheric Administration and the Office of Naval Research

Alverson K (2008a) Filling the gaps in GOOS. J Ocean Technol 19-20

Alverson K (2008b) Power point presentation given at the ocean tracking network (OTN) conference held at Dalhousie University, in Halifax, Nova Scotia, Canada, on 5-6 June 2008 at slide 15, available under http://www.ioc-goos.org/index.php?option=com_oe\&task=viewDocumentRecord\&docID=2105

Alverson K (2008c) The Global Ocean Observing System (GOOS), Hydro International

Alverson K, Baker DJ (2006) Taking the pulse of the oceans. Science 314 Editorial

Baker DJ (2003) Global ocean observing systems and the challenges of the 21 st century. In: Dahlin H, Fleming NC, Nittis K, Petersson SE (eds) Building the European capacity in operational oceanography. Elsevier, Amsterdam, pp 5-9

Baker DJ (2009) Planning and implementation for GOOS. A consultant study prepared for the IOC and the WMO, 28 May

Ehlers P (2000) The intergovernmental oceanographic commission: an international organisation for the promotion of marine research. Int J Marine Coastal Law 15(4):533-552

European Commission (2007) Commission staff working document SEC (2007) 1278, p 9

Evan MD (2006) International law, 2nd edn. Oxford University Press, Oxford

Gorina-Ysern M (2002) An international regime for marine scientific research. Transnational Publishers, Ardsley

Graf Vitzthum W (2006) Handbuch des Seerechts

Ilyina T (2006) Organising a global ocean observing system. In: Ehlers P, Lagoni R (eds) International maritime organisations and their contribution towards a sustainable marine development. Schriften zum See- und Hafenrecht, Bd.12, pp 181-196. Hamburg 
Information Document, GOOS Project Office, IOC/UNESCO (2009) The global ocean observing system, a summary for policy makers, p 4, available under: http://www.ioc-goos.org/component/option, com_oe/task, viewDocumentRecord/docID,4540/

Mann Borgese E (1999) Mit den Meeren leben. Über den Umgang mit den Ozeanen als globaler Ressource. Kiepenheuer \& Witsch, Köln

Mateos A, Gorina-Ysern M (2010) Climate change and guidelines for Argo Profiling float deployment on the high seas. Am Soc Int Law Insights 14(8)

Nordquist MH, Rosenne S, Yankov A, Grandy NR (eds) (1999) United nations convention on the law of the sea 1982, a commentary, vol IV, articles 192 to 278. Nijhoff, Nordrecht

Roach JA (2008) Marine data collection: MSR, surveys, operational oceanography, exploration and exploitation. Revue Egyptienne De Droit International 64:79-109

Ryder P (2003) Marine Scientific Research and Operational Oceanography in the Context of the UN Convention on the Law of the Sea, Report at the request of the I-GOOS Chair, IOC-WMO-UNEP/IGOOS-VI/10; Sixth Session of the IOC-WMO-UNEP Committee for the GOOS

Tromp D, Fleming NC (2002) A European approach to ocean observation. In: Ehlers P, Mann-Borgese E, Wolfrum R, Hoss C (eds) Marine issues: from a scientific, political and legal perspective. Kluwer Law International, The Hague, pp 279-298

Verlaan PA (2009) Current legal developments: International Oceanographic Commission of the United Nations Educational, Scientific and Cultural Organization (IOC/UNESCO). Int J Marine Coast Law 24:173-183

Wegelein FHT (2005) Marine scientific research - the operation and status of research vessels and other platforms in international law. Nijhoff, Leiden

Wolfrum R, Matz N (2003) Conflicts in international environmental law. Springer, Berlin 